\title{
PELATIHAN INTERNET DAN POWERPOINT UNTUK GURU-GURU DI SEKOLAH DASAR NEGERI 19 KOTA SABANG
}

\author{
Taufiq Iqbal $^{1 *}$, Rizaldi Akbar ${ }^{2}$ \\ ${ }^{1,2}$ AMIK Indonesia \\ *E-mail: taufiqiqbal@amikindonesia.ac.id
}

\begin{abstract}
ABSTRAK
Teknologi informasi mewajibkan pendidik setidaknya mampu memahami dan mengoperasionalkan serta mengakses internet dalam memanfaatkan media komunikasi melalui email, social media video blog, dan sejenisnya dengan tujuan untuk pendidikan. Serta tuntutan dalam melakukan persentasi bagi kalangan pendidik diperlukan juga untuk menjadikan suasana kualitas dan lingkungan belajar kreatif. Begitu juga bagi kalangan guru-guru Sekolah Dasar khususnya SD N 19 Kota Sabang. Kendala masih ada mengingat persentase guru yang mampu memanfaatkan internet dan powepoint masih kecil. Seperti SDN 19 Kota Sabang, hanya sekitar 2 orang guru yang biasa memakai internet dan Powerpoint, sedang guru lainnya belum bisa mengoperasikan internet. Untuk mencoba mengatasi permasalahan di SDN 19 Kota Sabang tersebut maka tim pengabdian AMIK Indonesia memiliki upaya dan peran untuk meningkatkan pendidikan di Kota Sabang tersebut melalui pelatihan internet dan powerpoint yang nantinta akan diikuti oleh guru-guru dari SD tersebut. Berdasarkan hasil pengamatan dan evaluasi, dari kegiatan pelatihan melibatkan materi, praktik, dan tugas maka diketahui bahwa tingkat pemahaman guru setelah mengikuti kegiatan pelatihan internet dan Powerpoint meningkat dengan persentase keberhasilan 85\%. Pelatihan internet dan Powerpoint ini telah dilaksanakan selama 2 hari pada tanggal 29 Agustus 2019 dengan jumlah peserta 10 guru, dan kegiatan ini juga berhasil meningkatkan kemampuan dan pengetahuan guru dan secara tidak langsung dapat berdampak kualitas anak didik yang berimbas pada peningkatan kualitas SDM lulusan SD tersebut.
\end{abstract}

Kata kunci: pengabdian; pelatihan; internet; powerpoint, guru.

\section{INTERNET TRAINING AND POWERPOINT FOR TEACHERS AT 19 ELEMENTARY SCHOOLS OF SABANG CITY}

\begin{abstract}
Information technology requires educators to at least be able to understand and operationalize and access the internet in utilizing communication media via email, social media video blogs, and the like for the purpose of education. As well as the demands in making presentations for educators it is also necessary to make an atmosphere of quality and creative learning environment. Likewise for elementary school teachers especially SD $N 19$ Sabang City. Constraints still exist considering the percentage of teachers who are able to use the internet and powepoint is still small. Like SDN 19 Sabang City, only about 2 teachers used to use the internet and PowerPoint, while other teachers could not operate the internet. To try to overcome the problems in SDN 19 Sabang City, the AMIK Indonesia service team has an effort and role to improve education in the Sabang City through internet training and powerpoints that will be followed by teachers from the elementary school. Based on observations and evaluations, from the training activities involving materials, practices, and assignments it is known that the level of understanding of teachers after participating in internet and Powerpoint training activities increased with a percentage of success of 85\%. This internet and Powerpoint training was held for 2 days on August 29, 2019 with a total of 10 teachers, and this activity also succeeded in increasing the ability and knowledge of teachers and could indirectly impact the quality of students that impact on improving the quality of the elementary school human resources.
\end{abstract}

Keywords: service; training; Internet; PowerPoint, teacher

\section{PENDAHULUAN}

Pendidikan merupakan bagian dari sistem kehidupan dalam masyarakat dengan tujuan sebagai suatu proses perkembangan dan perubahan dalam kelompok masyarakat [1]. Tuntutan dunia kerja dengan mengikuti sejalan perkembangan teknologi informasi menuntut iklim kualitas dari suatu 
BAKTI BANUA : Jurnal Pengabdian Kepada Masyarakat

Volume 1 No. 1 Mei 2020

https://ejurnal.stimi-bjm.ac.id/index.php/BBJM/

lembaga pendidikan [2,3] untuk benar-benar menghasilkan lulusan yang berkualitas dan memiliki daya saing kuat $[3,4]$.

Salah satu upaya untuk membentuk pendidikan yang berkualitas juga memperhatikan pengetahuan dan Pengembangan kepada pendidik agar nantinya mereka mampu menciptakan lulusan atau anak didik sesuai dengan perencanaan yang dilakukan [4,5], dimana setidaknya harus berkualitas [6], mandiri [7] dan produktif [8]. Perguruan tinggi memiliki peran di pendidikan dengan fungsi strategis dalam menunjang pengembangan teknologi dan ilmu pengetahuan [8]. Namun demikian dalam menjalankan misi sebagai lembaga pendidikan tinggi harus mampu mengikuti perkembangan teknologi dan informasi untuk mereduksi ketinggalan atau diskomunikasi dengan dunia luar $[9,10]$.

Teknologi informasi yang diwajibkan bagi pendidik setidaknya mampu memahami dan mengoperasionalkan serta mengakses halaman internet melalui jaringan [11]. Tidak hanya dapat mengakses sebuah ilmu pengetahuan tertentu, tetapi juga dalam memanfaatkan media komunikasi melalui email, social media video blog, dan sejenisnya dengan tujuan untuk pendidikan [12]. Kebutuhan orang untuk memanfaatkan fasilitas email internet semakin meningkat, seiring dengan pertumbuhan internet yang ada di instansi-instansi baik pemerintah maupun non pemerintah [13]. Tidak hanya di instanasi dan perkantoran di beberapa Sekolah Dasar (SD) Negeri Kota Sabang beberapa yang telah memiliki jaringan internet sebagai sarana koneksitas dengan dunia luar. Namun beberapa kendala masih ada mengingat persentase guru yang mampu memanfaatkan internet dan powepoint masih kecil. Seperti SDN 19 Kota Sabang, hanya sekitar 2 orang guru yang biasa memakai internet dan Powerpoint, sedang guru lainnya belum bisa mengoperasikan internet. Untuk mencoba mengatasi permasalahan di SDN 19 Kota Sabang tersebut maka tim pengabdian AMIK Indonesia memiliki upaya dan peran untuk meningkatkan pendidikan di Kota Sabang tersebut melalui pelatihan internet dan powerpoint yang nantinta akan diikuti oleh guru-guru dari SD tersebut. Dengan pelatihan ini diharapkan para guru mampu menggunakan internet dan powerpoint untuk keperluan penyerapan dan pengembangan ilmu pengetahuan serta memanfaatkan internet sebagai sarana komunikasi dan Powerpoint untuk media presentasi serta dapat menggunakan internet baik untuk sarana komunikasi (melalui E-mail) maupun Powerpoint untuk sarana presentasi.

\section{Tujuan Pengabdian Kepada Masyarakat}

Tujuan kegiatan pengabdian kepada masyarakat ini adalah untuk melatih Guru-guru SDN 19 Kota Sabang untuk mampu memanfaatkan dan menggunakan internet dan powerpoint untuk guruguru di sebagai sarana dan media komunikasi (E-mail) maupun presentasi.

\section{Manfaat Pengabdian Kepada Masyarakat}

Adapaun manfaat yang diharapkan dari kegiatan pelatihan ini adalah dapat meningkatkan kemampuan dan pengetahuan yang diperoleh, sehingga dapat menambah referensi bagi guru kepada anak didik yang berimbas pada peningkatan kualitas SDM lulusan SD tersebut.

\section{METODE}

\section{Lokasi Pengabdian}

Lokasi pengabdian ini pada SD N 19 Kota Sabang yang beralamat pada Kelurahan Paya Seunara Kecamatan Sukakarya Kota Sabang.

\section{Ruang Lingkup Pengabdian}

Adapun ruang lingkup utama dari kegiatan pengabdian kepada masyarakat ini adalah untuk meningkatkan mutu tenaga pengajar yaitu guru terutama dalam bidang komputer dan media pembelajaran, sehingga nantinya guru-guru di SD N 19 Kota Sabang memiliki kemampuan dan dalam menerapkan teknologi informasi yaitu dengan pelatihan internet sehingga mampu memanfaatkan sarana yang ada di internet untuk kepentingan komunikasi (E-mail), serta meningkatkan kemampuan dan kompetensi guru dalam media pembelajaran melalui pelatihan Powerpoint untuk sarana presentasi. 
BAKTI BANUA : Jurnal Pengabdian Kepada Masyarakat

Volume 1 No. 1 Mei 2020

https://ejurnal.stimi-bjm.ac.id/index.php/BBJM/

\section{Kelompok Sasaran}

Pelatihan ini difokuskan kepada Guru SD N 19 Kota Sabang dan peserta sebanyak 10 peserta.

\section{Metode Pengabdian}

1. Materi Kegiatan Internet

Pelatihan Internet untuk guru "SD N 19 Kota Sabang" dilaksanakan dengan metode ceramah, diskusi dan praktik. Metode Ceramah dilakukan dengan memberikan penjelasan cara browsing, searching, downloading, dan e-mail. Pada metode kedua yaitu diskusi dilakukan dengan memberikan waktu bila ada pertanyaan atau tanggapan dari peserta. Metode ketiga yaitu praktik langsung di komputer sesuai yang sudah di jelaskan sebelumnya, sambil instruktur mengamati perkembangan praktik para guru tersebut. Proses pelatihan dilaksanakan selama 2 kali pertemuan masing-masing selama 4 jam. Selama proses pelatihan, peserta diberikan modul pelatihan yang dipakai untuk acuan pelatihan. Adapun materi modul internet yang direncanakan dipakai pada pelatihan ini meliputi; a) Browsing; b) Teknik Searching; dan c) Pengenalan situs-situs penting dan down load file.

2. Materi Kegiatan Powerpoint

Powerpoint merupakan salah satu paket dari program Microsoft Office [14]. Pada Microsoft Office terdapat berbagai program seperti Microsoft Word, Microsoft Excell, Microsoft Powerpoint, Microsoft Oulook, Microsoft Access, dan sebagainya [15, 16]. Powerpoint adalah paket program yang digunakan untuk membantu pembuatan bahan bagi keperluan presentasi [17]. Berbagai daya dukung untuk pembuatan presentasi telah disediakan di program Powerpoint [18]. Secara garis besar Powerpoint dapat membuat tulisan bergerak, animasi halaman, dan sebagainya yang memungkinkan pengguna dapat berkreativitas agar dapat menjadi menarik [19].

\section{Rancangan Evaluasi}

Pada proses kegiatan pelatihan dilakukan dengan panduan modul yang memuat 2 (dua) materi pokok. Sedangkan untuk mengukur tingkat ketercapaian kegiatan pelatihan dilakukan dengan evaluasi bersamaan saat proses pelatihan dilakukan, yang artinya setiap masing-masing peserta yang mengikuti pelatihan dipantau oleh instruktur, dan langsung dibimbing apabila mengalami kendala dalam menyelesaikan tugas dan Latihan yang diberikan. Sebelumnya, peserta dibekali penjelasan awal dari materi yang diberikan, kemudian dibimbing dalam melaksanakan setiap perintah yang ada di modul pelatihan. Setiap langkah tersebut dinilai dengan lembar evaluasi, apabila ada bagian yang belum dipahami oleh peserta, instruktur wajib menerangkan kembali sehingga peserta betul-betul mampu menjalankan program Microsoft Powerpoint dan internet.

\section{Rencana dan Jadwal Kerja}

Pelaksanaan program pelatihan ini dari persiapan hingga pelaporan dilakukan selama 3 bulan, yaitu dimulai pada pertengahan bulan Juni 2019 sampai Agustus 2019. Adapun jadwal kerja secara rinci ditampilkan pada tabel 1 , sebagai berikut :

Tabel 1. Jadwal Rencana Kegiatan Pelaksanaan Program Pelatihan

\begin{tabular}{|c|c|c|c|c|c|c|c|c|}
\hline \multirow{2}{*}{ No } & \multirow{2}{*}{ Jenis Kegiatan } & \multicolumn{2}{|c|}{ Juni } & \multicolumn{4}{|c|}{ Juli } & \multirow{2}{*}{$\frac{\text { Agustus }}{\text { I }}$} \\
\hline & & $\mathbf{I}$ & II & I & II & III & IV & \\
\hline 1 & Kesepakatan program pelatihan & & & & & & & \\
\hline 2 & $\begin{array}{l}\text { Persiapan waktu dan tempat } \\
\text { pelatihan }\end{array}$ & & & & & & & \\
\hline 3 & Persiapan modul pelatihan & & & & & & & \\
\hline 4 & Pelaksanaan Pelatihan & & & & & & & \\
\hline 5 & Evaluasi & & & & & & & \\
\hline 6 & $\begin{array}{l}\text { Penyerahan hasil pelatihan dan } \\
\text { pembuatan laporan }\end{array}$ & & & & & & & \\
\hline
\end{tabular}




\section{HASIL DAN PEMBAHASAN} Hasil Pelaksanaan Kegiatan

Adapun bentuk langkah-langkah kongkrit yang dilaksanakan dalam pelatihan ini sehingga pelatihan ini dapat berhasil dilaksanakan meliputi; a) Melakukan identifikasi materi jaringan internet dan Powerpoint dengan menanyakan langsung kepada Kepala Sekolah dan Guru ketua lab komputer yang ada di SD N 19 Kota Sabang, b) Melakukan pelatihan internet dan Powerpoint dengan mengikuti panduan modul, dan c) Melakukan pemantauan serta diskusi pemecahan masalah untuk menyelesaikan tugas-tugas yang diberikan.

Berdasarkan pengamatan dan evaluasi yang dilakukan selama kegiatan pelatihan, dapat diketahui bahwa kegiatan PPM yang bertempat di SD N 19 Kota Sabang telah berhasil dilaksanakan dengan materi pelatihan internet dan Powerpoint yang dilaksanakan selama 2 hari dengan kisaran waktu selama $10 \mathrm{jam}$. Indikator keberhasilan yang telah dicapai dalam pelatihan ini dapat dilihat dari pencapaian kompetensi guru selama pengamatan selama proses pelatihan, yaitu:

a. Guru dapat melakukan browsing dan searching melalui fasilitas pencarian internet menggunakan www.google.com dan www.yahoo.com

b. Peserta dapat mencari bahan-bahan pembelajaran dari berbagai situs yang tersedia secara gratis.

c. Peserta dapat membuat, mengirim dan mengirim pesan melalui e-mail GMAIL..

d. Peserta dapat membuat persentasi dari Powerpoint yang melibatkan tulisan, menyematkan gambar, dan mengatur animasi untuk kebutuhan presentasi.

\section{Faktor Pendukung}

Faktor pendukung keberhasilan kegiatan pelatihan ini adalah adanya dukungan dana dari pihak AMIK Indonesia serta sudah adanya laboratorium komputer yang sudah dilengkapi jaringan internet yang ada di SD N 19 Kota Sabang. Selain itu, motivasi guru dalam mengikuti kegiatan pelatihan dalam keikutsertaan dan kedisiplinan waktu pada saat mengikuti sesi pelatihan.

\section{Faktor Penghambat}

Adapun faktor penghambat yang ditemukan tidak terdampak pada keberhasilan kegiatan, namun hambatan hanya pada jadwal pelaksanaan yang harus disesuaikan antara tim PPM (dosen AMIK Indonesia) dan guru, serta rendahnya konektivitas jaringan internet yang tersedia sehingga Tim PPM mengambil langkah dalam penyiapan koneksi alternatif menggunakan modem maupun hotspot.

\section{Evaluasi}

Evaluasi dilakukan merujuk dari aktifitas kegiatan pelatihan berlangsung yang terlihat langsung dari penguasaan materi dan penyelesaian tugas-tugas yang diberikan. Sasaran peserta berdampak meningkatkan kualitas dari para guru-guru di lingkungan SD N 19 Kota Sabang, sehingga secara tidak langsung dapat meningkatkan kualitas murid-murid di SD tersebut. Kegiatan PPM dengan tema "Pelatihan internet dan Powerpoint di SD N 19 Kota Sabang" telah dilaksanakan selama 2 hari yaitu pada tanggal 29 Agustus 2019 yang dimulai jam 13.00 sampai jam 17.00 WIB dengan jumlah peserta 10 guru, dan tanggal 31 Agustus 2019 mulai jam 13.00 sampai 17.00 WIB dengan jumlah peserta 9 guru.

Pelatihan ini melibatkan 2 (dua) orang instruktur dari Tim PPM dan 2 (dua) orang Dosen yang memiliki keahlian bidang Internet dan Microsoft Office. Materi disampaikan melalui media infocus dan juga diberikan modul baik dalam bentuk soft maupun hardcopy kepada peserta sehingga dapat memudahkan pemateri dalam menjelaskan modul dan rencana kegiatan pelaksanaan pelatihan. Instruktur pendamping atau tim PPM mahasiswa membantu dan mengarahkan guru dalam mengoperasionalkan komputer dan berbagai penjelasan serta latihan kepada guru. Dari pengamatan hasil pelatihan, terlihat guru-guru mengikuti pelatihan dengan sangat antusias. Hal ini juga terlihat setiap ada hal yang belum jelas disampaikan instruktur, guru langsung menanyakan kepada instruktur, terutama kepada instruktur pendamping. Beberapa kesulitan kecil, sebagian kecil guru belum begitu mengenal komputer, sehingga harus mengajari dulu dasar-dasar komputer. 


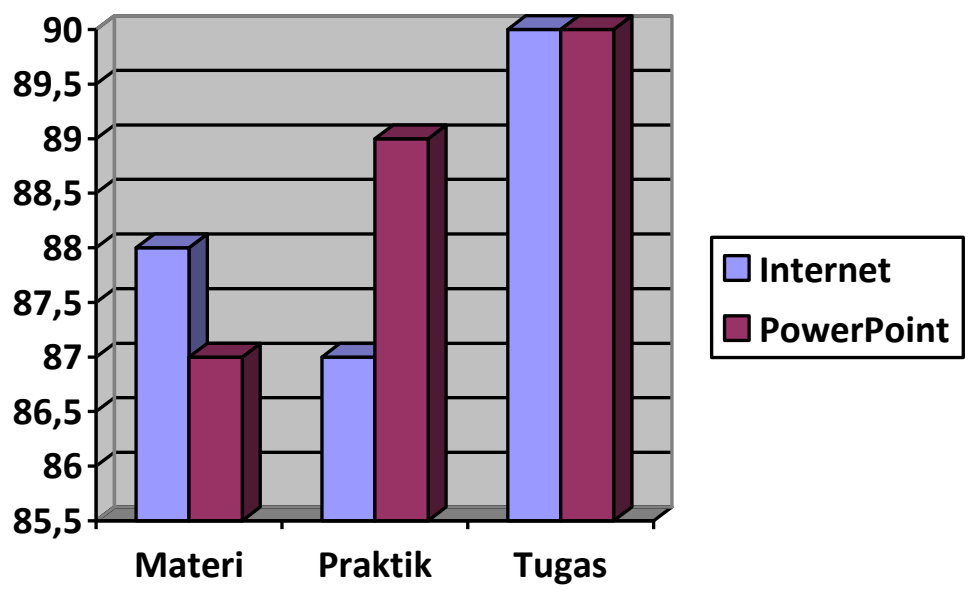

Gambar 1. Tingkat Pemahaman Guru (\%)

Dari kegiatan pelatihan melibatkan materi, praktik, dan tugas maka diketahui bahwa tingkat pemahaman guru dalam memahami materi yang disampaikan sebesar $88 \%$ memahami materi internet dan $87 \%$ memahami materi Powerpoint. Pada tingkat pemahaman praktik dapat dilihat dari kegiatan dalam menguasai modul yang diberikan, terlihat penguasaan praktik internet sebesar $87 \%$ sedangkan pada Powerpoint sebesar $89 \%$. Sedangkan pada penguasaan dan penyelesaian tugas-tugas yang diberikan terlihat kemampuan dalam menyelesaikan tugas sebesar $90 \%$ pada tugas internet dan Powerpoint.

Selama 2 hari tersebut, pada hari pertama peserta yaitu para guru SD N 19 Kota Sabang telah berhasil mempraktikkan materi internet yaitu Browsing, Searching, Downloading, dan mengelola akun E-mail. Pada hari kedua, peserta juga telah berhasil mempraktikkan materi Powerpoint dengan membuat tulisan, membuat rancangan tampilan, mengatur animasi tampilan untuk presentasi. Melihat dari pentingnya fungsi dari penggunaan internet dan Powerpoint untuk pengembangan sekolah, maka sekolah yang telah memiliki jaringan komputer ke internet perlu diadakan pelatihan seperti ini, sehingga pemanfaatan fasilitas yang sudah tersedia disekolah tersebut dapat dimanfaatkan semaksimal mungkin untuk mendukung kualitas SDM maupun kualitas PBM disekolah tersebut.
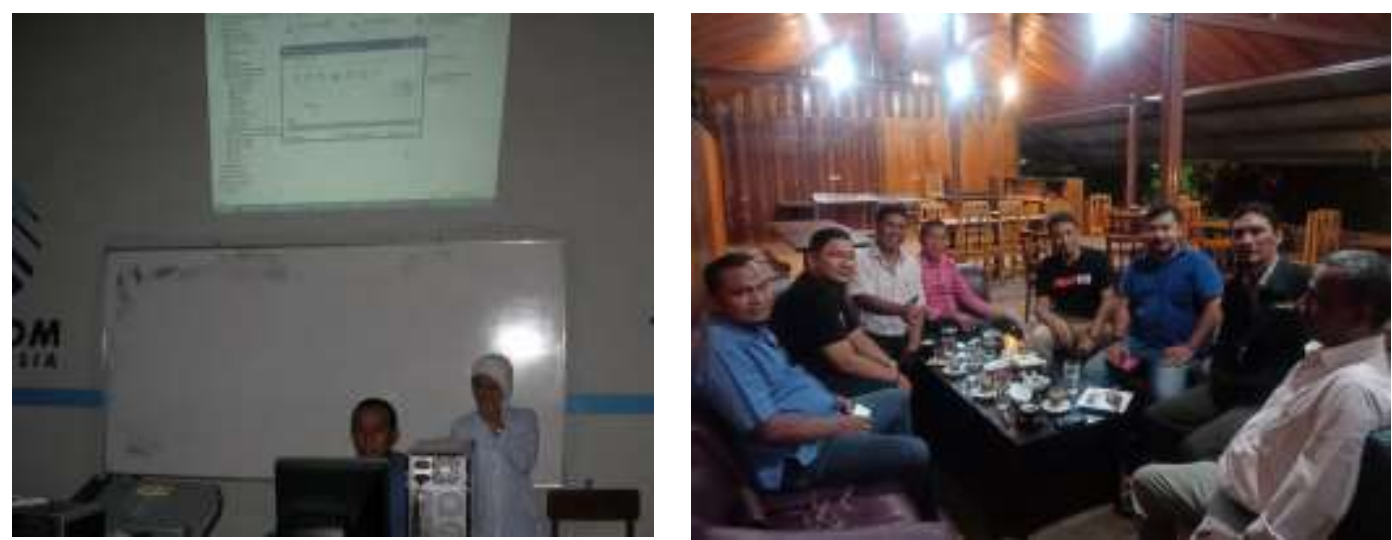

Gambar 2. Kegiatan Pelaksanaan Pelatihan dan Rapat Gampong 


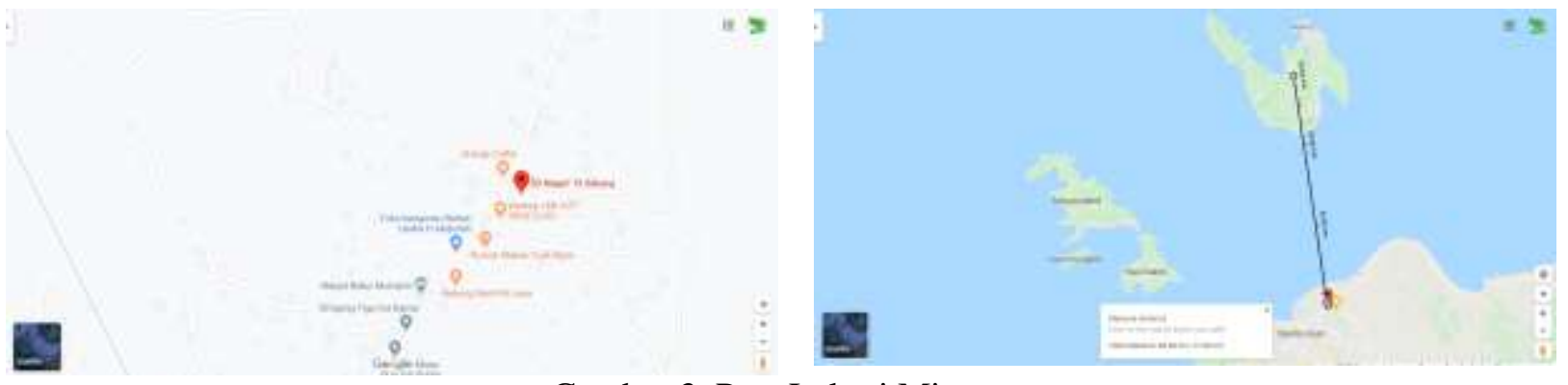

Gambar 3. Peta Lokasi Mitra

\section{SIMPULAN}

Adapun simpulan yang dirangkum dari hasil pengabdian yang telah dilakukan adalah:

a. Tim PPM dari AMIK Indonesia telah berhasil melaksanakan program pelatihan internet dan Powerpoint di SD N 19 Kota Sabang.

b. Sekolah SD N 19 Kota Sabang yang telah memiliki jaringan internet memerlukan pelatihan internet dan Powerpoint sebagai upaya meningkatkan kualitas guru.

c. Guru- guru di SD N 19 Kota Sabang memberikan tanggapan yang antusias pada pelatihan ini dilihat dari jumlah kehadiran guru maupun respon saat pelatihan.

d. Terjalin kemitraan dan kerjasama antara pihak AMIK Indonesia dan SD N 19 Kota Sabang.

\section{UCAPAN TERIMAKASIH (jika ada)}

Ucapan terima kasih sebesar-besarnya kepada LPPM AMIK Indonesia sebagai penyandang dana kegiatan pengabdian tidak lupa pula kepada Dosen-Dosen AMIK Indonesia, Staff Akademik beserta anggota pengabdian yang terdiri dari mahasiswa dan alumni AMIK Indonesia.

\section{DAFTAR PUSTAKA}

Herawan, K.D. and Sudarsana, I.K., 2017. Relevansi Nilai Pendidikan Karakter Dalam Geguritan Suddhamala Untuk Meningkatkan Mutu Pendidikan Di Indonesia. Jurnal Penjaminan Mutu, 3(2), pp.223-236.

Akbar, R., 2018. Perancangan Aplikasi Perangkingan Perguruan Tinggi Menggunakan Fuzzy Simple Additive Weighting (SAW)(Studi Kasus: 25 PT Wilayah Kopertis XIII Provinsi Aceh). Jurnal JTIK (Jurnal Teknologi Informasi dan Komunikasi), 2(1), pp.1-10.

Akbar, R. and Mukhtar, M., 2020. Perancangan E-Tracer Study berbasis Sistem Cerdas. Jurnal Sisfokom (Sistem Informasi dan Komputer), 9(1), pp.8-12.

Akbar, R. and Mukhtar, M., 2019. Evaluasi e-Tracer Study menggunakan HOT (Human-OrganizationTechnology) Fit Model. Jurnal JTIK (Jurnal Teknologi Informasi dan Komunikasi), 3(2), pp.46-51.

Arifin, S., 2017. Revitalisasi Keluarga Sebagai Lingkungan Pendidikan. Jurnal Kariman, 5(1), pp.122.

Ramdani, Z., 2018. Kolaborasi antara kepala sekolah, guru dan siswa dalam menciptakan sistem pendidikan yang berkualitas. In National Conference on Educational Assessment and Plolicy.

Maryono, M., Budiono, H. and Okha, R., 2018. Implementasi Pendidikan Karakter Mandiri Di Sekolah Dasar. Jurnal Gentala Pendidikan Dasar, 3(1), pp.20-38. 
BAKTI BANUA : Jurnal Pengabdian Kepada Masyarakat

Volume 1 No. 1 Mei 2020

https://ejurnal.stimi-bjm.ac.id/index.php/BBJM/

Dimas, P. and Simanjuntak, D., 2017. Pengaruh Pendidikan Dan Pelatihan Terhadap Produktivitas Kerja Pada Kantor Cabang Dinas Pendidikan Kecamatan Kualuh Hulu Labuhanbatu Utara. ECOBISMA (Jurnal Ekonomi, Bisnis dan Manajemen), 4(2), pp.64-76.

Dacholfany, M.I., 2017. Inisiasi Strategi Manajemen Lembaga Pendidikan Islam Dalam Meningkatkan Mutu Sumber Daya Manusia Islami di Indonesia Dalam Menghadapi Era Globalisasi. At-Tajdid: Jurnal Pendidikan dan Pemikiran Islam, 1(01).

Khumaidi, A., 2020. PERANAN TEKNOLOGI INFORMASI SEBAGAI MEDIA INFORMASI PEMERINTAH DI DINAS PENDIDIKAN KABUAPTEN TANGGAMUS. Jurnal PkM Pemberdayaan Masyarakat, 1(1), pp.6-10.

Rizal, S. (2020) "PKM : Pemberdayaan Generasi Muda Melalui Enterpreneurship di Gampong Leuge Kecamatan Peureulak Kabupaten Aceh Timur", TRIDARMA: Pengabdian Kepada Masyarakat (PkM), 3(1, Mei), pp. 35-39.

Wali, M. and Mukhtar, M. (2020) "PKM : Pelatihan Microsoft Excel 2013 Dalam Rangka Membentuk Tenaga Pengajar Yang Profesional”, TRIDARMA: Pengabdian Kepada Masyarakat (PkM), 3(1, Mei), pp. 31-34.

Rahardja, U., Harahap, E.P. and Pratiwi, S., 2018. Pemanfaatan Mailchimp Sebagai Trend Penyebaran Informasi Pembayaran Bagi Mahasiswa Di Perguruan Tinggi. Technomedia Journal, 2(2), pp.41-54.

Wali, M., 2018. Add-ins Microsoft Office. (Vol. 1). KITA Publisher.

Akbar, R., 2019. Modul Praktikum Microsoft Office Excel : 10 Hari Bisa. KITA Publisher.

Munawir, M., 2019. Modul Program Aplikasi Paket Microsoft Office Word. KITA Publisher.

Juanita, S., Hayati, P. and Sakti, D.V.S.Y., 2019. PENINGKATAN KETERAMPILAN MENYAJIKAN PRESENTASI MENARIK DAN INTERAKTIF BAGI GURU PKBM NEGERI 27 PETUKANGAN DENGAN PELATIHAN MICROSOFT POWER POINT. Sebatik, 23(2), pp.528-533.

Nugroho, G.K., 2012. Optimalisasi Microsoft Office Powerpoint 2010 Dalam Pembuatan Media Interaktif Penggandaan Dokumen Untuk Program Keahlian Administrasi Perkantoran Sekolah Menengah Kejuruan Negeri 1. Speed-Sentra Penelitian Engineering dan Edukasi, 4(2).

Winder, C. and Dowlatabadi, Z., 2019. Producing Animation 3e. CRC Press. 